\title{
Functional Unit for Impact Assessment in the Mining Sector-Part 1
}

\author{
Julien Bongono $^{1}$, Birol Elevli ${ }^{2}$ and Bertrand Laratte $1,2,3,4, * \mathbb{D}$ \\ 1 Arts et Métiers Institute of Technology, University of Bordeaux, CNRS, Bordeaux INP, INRAE, \\ I2M Bordeaux, F-33400 Talence, France; julien.bongono@ac-bordeaux.fr \\ 2 Department of Industrial Engineering, Ondokuz Mayıs University, Samsun 55139, Turkey; \\ birol.elevli@omu.edu.tr \\ 3 APESA-Innovation, F-40220 Tarnos, France \\ 4 French Institute of Anatolian Studies, CNRS USR 3131, Palais de France Nur-i Ziya, sk. 10 PK 5434433 \\ Beyoğlu, Istanbul, Turkey \\ * Correspondence: bertrand.laratte@ensam.eu
}

Received: 13 October 2020; Accepted: 9 November 2020; Published: 10 November 2020

check for updates

\begin{abstract}
More and more efforts are directed towards the standardization of the methods of determining the functional unit (FU) in a Life Cycle Assessment (LCA). These efforts concern the development of theories and detailed methodological guides, but also the evaluation of the quality of the FU obtained. The objective of this article is to review this work in order to propose, using a multiscale approach, a method for defining the FU in the mining sector, which takes into account all the dimensions of the system under study. In this first part, the emphasis is on identifying the shortcomings of the FU. The absence of a precise normative framework specific to each sector of activity, as well as the complex, multifunctional and hard-to-scale nature of the systems concerned, are at the origin of the flexibility in the selection of the FU. This lack of a framework, beyond generating a heterogeneous definition of the FU for the same system, most often leads to an incomplete formulation of this sensitive concept of LCA. It has been found that key parameters such as the end-use of a product or process, as well as the interests of stakeholders, are hardly taken into account in the specification of the FU.
\end{abstract}

Keywords: functional unit; LCA methodological framework; system boundary; reference flow; impact assessment; mining sector

\section{Introduction}

The emergence of Life Cycle Assessment (LCA)-type studies dates to the late 1960s. LCA was recognized worldwide as one of the tools for analyzing environmental problems in 1988 [1]. Even though it had already been used in certain industrial sectors, it was from 1990 that methodological developments and the standardization process began to harmonize in practice [2]. Three decades later, the methodological framework defined by the series of standards ISO14040 to ISO $14044(2006)[3,4]$ is generally accepted as a reference. It is made up of four main stages: the goal and scope definition, the inventory analysis, the impact assessment, and the interpretation. This normative and iterative framework is effective in terms of conducting LCA and presenting the analysis results, which have therefore become more robust, reproducible, and reliable.

One of the main strengths of this normative framework is its flexibility to be adapted to all sectors of human activity. A wide flexibility is left to practitioners and researchers in its application, in particular when defining the central concept of a functional unit (FU). But from another point of view, this flexibility is also a flaw because it generates problems of uniformity of practices that must be resolved. 
However, with all standards and normative frameworks, one can observe some lacks and limitations in order to conduct an LCA in the mining sector. This paper aims to review mining LCA, and especially the FU, and identify the key points and a critical analysis. This paper also aims to identify the missing points in the FU that could be considered in order to avoid some parameters that could be used to compare different mining processes.

\subsection{Problems of Uniformity of Functional Unit and Variability of LCA Results}

The representativeness and the value of the results of an LCA depend on the robustness, the reproducibility and the reliability of the choices that are made during the execution of the four steps of the analysis. Reap et al. [5] identified 15 points of vulnerability across all stages of LCA methodology. Six of the 15 vulnerability issues are rated as critical. On a severity scale of 1 to 5 , the definition of the $\mathrm{FU}$ is positioned on level 4, making this critical step a particular point of attention when performing an LCA. This weakness of LCA due to the definition of the FU is probably because of the absence of a detailed normative framework for each sector of activity and specific context, which leaves a significant amount of subjectivity to LCA analysts. The FU is thus defined in an arbitrary manner, generating, for the same case study, a significant variability in its formulation [6]. In addition, the FU tends to be defined in a simplistic or insufficient way [7] because only the main functions and constraints are taken into account, and are not necessarily representative of all the impacts at stake. For the same system, the formulation of the FU can be done in different ways, so that its final form depends on who carries out the LCA.

Studies show that the choice of FU can affect the LCA results, going so far as to alter the apparent favorable option. The study of bio-based energy options [8], that of the analysis of E10 and E85 fuels [9], that of the analysis of electric vehicle batteries [10], or that of the study of the boron industry $[11,12]$ are some examples of studies where the choice of the functional unit has significantly influenced the LCA results.

\subsection{Difficulties in Selecting the Functional Unit}

Methodological development is continuing, but many difficulties related to the selection of the FU persist. These difficulties are generally observed when studying multifunctional systems, or when dealing with systems for which it is particularly difficult to define the FU [13-15]. These are referred to hereafter as hard-to-scale systems. Langfitt notes six difficulties linked to the definition of the FU [16]: the choice to include all the functions or only part of the functions of the system in the definition of the FU; the taking into account of both quantitative and qualitative functions; prioritization of functions; uncertainty about the end use of the product; taking stakeholder interests into account; and the avoidance of bias and generalization. In the absence of concise and precise guidance, it is not uncommon, even unintentionally, to give in to these difficulties.

\subsection{Guidance for the Selection of the Functional Unit}

There are many initiatives to guide the LCA analyst practitioner. They are the work, among others, of the international organization for standardization [3,4], the European Commission [17] and numerous researchers $[6,13,16,18-23]$. These guidelines show what the FU is, what it is not, and are sometimes complementary and become more precise, as shown in Table 1. 
Table 1. Guidance for the selection of the functional unit.

\begin{tabular}{|c|c|}
\hline Regulatory Bodies and Research Actors & Guidelines for Defining the Functional Unit \\
\hline International Organization for Standardization & $\begin{array}{l}\text { - } \text { "Quantify performance of a product system for use as a reference unit» } \\
\text { - «Specify the functions of the system being studied» } \\
\text { - «Clearly defined and measurable» } \\
\text { - The systems that are compared must have the same functional unit } \\
\text { - System functions that are not considered in the functional unit must be identified } \\
\text { and the omission must be explained }\end{array}$ \\
\hline European Commission & $\begin{array}{l}\text { - The functional unit should answer the following four questions: What? How } \\
\text { many? How well? For how long? } \\
\text { - The order of magnitude of the functional unit is irrelevant }\end{array}$ \\
\hline $\begin{array}{l}\text { UNEP-SLCA (United Nations Environment } \\
\text { Program for Social Life Cycle Assessment) }\end{array}$ & $\begin{array}{l}\text { - The product utility is required to be describe in functional terms, and the } \\
\text { practitioner should consider the social impacts of the product use phase } \\
\text { and function }\end{array}$ \\
\hline Researchers & $\begin{array}{l}\text { - The order of magnitude of the functional unit is in the order of a meaningful } \\
\text { quantity, such as annual production [21] } \\
\text { The order of magnitude of the functional unit is of the same order as the annual } \\
\text { per capita consumption of the product studied in its market segment [19] } \\
\text { - } \quad \text { Prioritize quantitative measurements for quality indicators [13] } \\
\text { Secondary functions should either be neglected or be dealt with in the following } \\
\text { hierarchical order: expansion of system boundaries/system } \\
\text { disaggregation/allocation [13,18,21] } \\
\text { - The function identified in the functional unit should be closest to the end use and } \\
\text { should be aligned with the objective of the study [20] } \\
\text { Define the functional unit on the functional basis rather than the physical aspect } \\
\text { of the system [19] } \\
\text { Follow the fuon theory approach when the evaluation relates to the impacts of a } \\
\text { system under design [20] } \\
\text { Judge the quality and appropriateness of the functional unit based on a } \\
\text { quantitative assessment and not only on the basis of good practices from the } \\
\text { literature [16] } \\
\text { - Use an active verb-noun pair as the first step in defining the functional unit [23] } \\
\text { Consider three factors for the definition of the functional unit: the order of } \\
\text { magnitude of the service provided by the system, the duration of the service and } \\
\text { the expected level of quality [6,13] } \\
\text { Define the main functions, any secondary functions and the constrained functions } \\
\text { of the system with the methods of functional analysis [6] } \\
\text { Structure each of these functions around the fourth ILCD Handbook element [6] }\end{array}$ \\
\hline
\end{tabular}

\section{Materials and Methods}

The objective of this study was to provide a concise methodology for determining FUs in the mining sector. A bibliographic search was carried out on the main scientific search engines (Google Scholar, Researchgate, Sciencedirect, Academia, Springer, etc.) to select the articles devoted to the methodology of life cycle analysis and to the methodological problems encountered during case studies. A focus was placed on articles dedicated specifically to the methodology for defining the FU. The selected articles were purposely from several industrial sectors, in order to constitute an inter-contextual corpus which made it possible to identify commonalities beyond the contextual variations of the methodology.

Due to the existence of a normative framework from 2006 (ISO 14000 series of standards), most of the articles examined dates from then until 2019. The following keywords were used for the search: Functional Unit, LCA methodology, Mining industry, Reference flow, Standardization. Nearly 10,000 studies (articles and theses combined) were found, including 15 relevant (13 articles and 2 theses) papers. This literature review focused on identifying the shortcomings of the methodology for defining the FU and establishing its variability depending on the types of LCA application. The critical analysis took place to specify the key parameters missing from the FU, necessary for the impact studies of the mining activity.

\section{Results}

\subsection{Putting the Difficulties Encountered and the Guidance of the LCA Literature into Perspective}

To better understand the role of each guideline, their perspective with the difficulties encountered in the practice of LCA is proposed in Table 2. Putting the guidelines and the difficulties encountered 
in defining the FU into perspective indicates which guidelines meet which difficulty. While there are a significant number of guidelines for certain difficulties, such as the choice to include all of the functions or only part of the functions of the system, the consideration of both quantitative and qualitative functions, and the avoidance of bias and generalization, other difficulties, on the other hand, such as the prioritization of functions, uncertainty about the end use of the product or taking into account the interests of stakeholders were found to have no guidance (or very little) present in the literature selected for this study. This lack of guidance means that the variability of LCA results due to the variability of the FU is still a significant problem. Developing concise industry-specific guidelines for specific contexts seems to be the solution [16].

Table 2. Putting the difficulties encountered and the guidance of the Life Cycle Assessment (LCA) literature into perspective. The guidelines in bold text are more consistent with multifunctional systems. Hard-to-scale systems are, by deduction, monofunctional.

\begin{tabular}{|c|c|}
\hline \multicolumn{2}{|r|}{ Multifunctional Systems/Hard-to-Scale Systems } \\
\hline Choice to include or exclude the functions & $\begin{array}{l}\text { - } \text { "Specify the functions of the system being studied» ISO 14044 [4] } \\
\text { - "Should be consistent with the goal and scope of the study» [4] } \\
\text { - } \quad \text { The systems that are compared must have the same functional unit ISO } 14044 \text { [4] } \\
\text { - Define the functional unit on the functional basis rather than the physical aspect of } \\
\text { - The system [19] } \\
\text { - The product utility is required to be described in functional terms, and practitioners } \\
\text { - The functions identified in the functional unit should be closest to the end use and } \\
\text { - Should be aligned with the objective of the study [20] } \\
\text { the omission must be explained [4] }\end{array}$ \\
\hline $\begin{array}{l}\text { Considering both quantitative and qualitative } \\
\text { functions }\end{array}$ & $\begin{array}{l}\text { - The functional unit should answer the following four questions: What? How many? } \\
\text { - How well? For how long? [17] } \\
\text { Consider three factors for the definition of the functional unit: the order of magnitude } \\
\text { of the service provided by the system; the duration of the service; and the expected } \\
\text { level of quality [6,13] } \\
\text { - Structure each of these functions around the fourth ILCD Handbook element }[6,17] \\
\text { - The order of magnitude of the functional unit is irrelevant [17] } \\
\text { The order of magnitude of the functional unit is in the order of a meaningful quantity, } \\
\text { - The order of magnitude of the functional unit is of the same order as the annual per } \\
\text { capita consumption of the product studied in its market segment [19] } \\
\text { - Prioritize quantitative measurements for quality indicators [13] }\end{array}$ \\
\hline Avoidance of bias and generalization & $\begin{array}{l}\text { - Follow the fuon theory approach when the evaluation relates to the impacts of a } \\
\text { system under design [22] } \\
\text { - Judge the quality and appropriateness of the functional unit based on a quantitative } \\
\text { assessment and not only on the basis of good practices from the literature [16] } \\
\text { - Use an active verb-noun pair as the first step in defining the functional unit [23] } \\
\text { - Define the main functions, any secondary functions, and the constrained functions of } \\
\text { the system with the methods of functional analysis [6] }\end{array}$ \\
\hline Prioritization of functions & $\begin{array}{l}\text { - Secondary functions should either be neglected or be dealt with in the following } \\
\text { hierarchical order: expansion of system boundaries/system disaggregation/allocation } \\
{[13,18,21]}\end{array}$ \\
\hline Uncertainty about the end use of the product & - \\
\hline Considering of stakeholder interests & - \\
\hline
\end{tabular}

\subsection{Definition of the Functional Unit in Different Industrial Sectors}

Industrial sectors are unique when they develop specific contexts surrounding the product (The term product will be used in the remainder of this text to designate either a product, a process, or a more complex technical system), process or system under study. Therefore, it seems that the development of concise guidance specific to each industrial sector is necessary for the definition of the FU. If the conciseness and precision of the guidance is not assured, it is possible to observe the differences in the formulation of the FU as shown in Table 3. This table summarizes seven different LCA studies, from different industrial sectors. Its purpose mainly concerns the first step of the LCA process: defining the goal and scope of the study. The salient elements of the table are the types of LCA application, the study objectives, and the FU column. It is important to point out that even though reading the table by row can be useful for understanding each study, it quickly becomes insufficient 
because the information is purposely truncated for the intents of this research. The privileged reading is therefore that by column. Five (5) distinct applications of LCA were identified out of the seven studies considered. They relate to the extraction of raw materials (process optimization), product design, process design, waste reduction (process selection) and product selection.

Table 3. Functional units (FUs) in different industrial sectors.

\begin{tabular}{|c|c|c|c|c|}
\hline LCA and Its Applications & Example of Study & Objective of the Study & Functional Unit & Reference Flow \\
\hline Process optimization & $\begin{array}{l}\text { Study 1: Boron mining } \\
\text { and processing }[11,25]\end{array}$ & $\begin{array}{l}\text { To improve the process } \\
\text { performance on the basis } \\
\text { of its actual operation } \\
\text { (internal use) }\end{array}$ & $\begin{array}{l}\text { «Operation of the system } \\
\text { for one year» (FU1) }\end{array}$ & $\begin{array}{l}\text { Quantities of material and } \\
\text { energy required to meet } \\
\text { operation requirements of the } \\
\text { system for one year }\end{array}$ \\
\hline Process optimization & $\begin{array}{l}\text { Study 2: Copper } \\
\text { mining [26] }\end{array}$ & $\begin{array}{l}\text { The identification (and } \\
\text { mitigation) of } \\
\text { environmental hotspots of } \\
\text { European copper } \\
\text { production }\end{array}$ & $\begin{array}{l}\text { «The production of } 1 \mathrm{~kg} \text { of } \\
\text { copper cathode» (FU2) }\end{array}$ & $\begin{array}{l}\text { Quantities of material and } \\
\text { energy required to produce } 1 \\
\text { kg of copper cathode }\end{array}$ \\
\hline Process optimization & $\begin{array}{l}\text { Study 3: Cobalt } \\
\text { extraction process }[27]\end{array}$ & $\begin{array}{l}\text { To analyze the } \\
\text { cradle-to-gate } \\
\text { environmental impact of } \\
\text { cobalt production }\end{array}$ & $\begin{array}{l}\text { «The production of } 1 \mathrm{~kg} \text { of } \\
\text { cobalt» }(\text { FU3) }\end{array}$ & $\begin{array}{l}\text { Quantities of material and } \\
\text { energy required to produce } 1 \\
\mathrm{~kg} \text { of cobalt }\end{array}$ \\
\hline Product design & $\begin{array}{l}\text { Study 4: Designing } \\
\text { grinding wheel [12] }\end{array}$ & $\begin{array}{l}\text { The determination of the } \\
\text { environmental impact for } \\
\text { one grinding wheel within } \\
\text { a cradle-to-gate and a } \\
\text { cradle-to-grave } \\
\text { perspective, respectively. } \\
\text { The assessment was based } \\
\text { on the demanded energy } \\
\text { and resource flows }\end{array}$ & $\begin{array}{l}\text { «The material extraction } \\
\text { and production phase of a } \\
\text { vitrified bonded grinding } \\
\text { wheel with a straight } \\
\text { profile, an external } \\
\text { diameter of } 400 \mathrm{~mm} \text {, width } \\
\text { of } 15 \mathrm{~mm} \text { and an abrasive } \\
\text { layer thickness of } 5 \mathrm{~mm} » \\
\text { (FU4) }\end{array}$ & $\begin{array}{l}\text { Quantities of material and } \\
\text { energy required to produce a } \\
\text { grinding wheel }\end{array}$ \\
\hline Process design & $\begin{array}{l}\text { Study 5: Grinding } \\
\text { process [12] }\end{array}$ & $\begin{array}{l}\text { The determination of the } \\
\text { environmental impact for } \\
\text { one grinding wheel }\end{array}$ & $\begin{array}{l}\text { «To produce } 12,000 \\
\text { workpieces with an } \\
\text { external cylindrical } \\
\text { grinding process» (FU5) }\end{array}$ & $\begin{array}{c}\text { Number of required grinding } \\
\text { wheels }\end{array}$ \\
\hline Process comparison & $\begin{array}{l}\text { Study 6: } \mathrm{SO}_{2} \\
\text { abatement }[25]\end{array}$ & $\begin{array}{l}\text { To compare different } \mathrm{SO}_{2} \\
\text { abatement techniques: wet } \\
\text { limestone/gypsum double } \\
\text { alkali and dry sodium } \\
\text { carbonate processes }\end{array}$ & $\begin{array}{l}\text { «Treatment of one ton of } \\
\mathrm{SO}_{2} \text { in the flue gas» (FU6) }\end{array}$ & $\begin{array}{l}\text { Quantities of material and } \\
\text { energy required to meet } \\
\text { treatment of one ton of } \mathrm{SO}_{2} \text { in } \\
\text { the flue gas }\end{array}$ \\
\hline Products comparison & $\begin{array}{l}\text { Study 7: HVFA } \\
\text { concrete [28] }\end{array}$ & $\begin{array}{c}\text { To quantify the } \\
\text { environmental benefits of } \\
\text { an OPC replacement with } \\
\text { fly ash }\end{array}$ & $\begin{array}{c}\text { «The amount of concrete } \\
\text { needed in a } 1 \mathrm{~m}^{3} \text { structure } \\
\text { with a service life of } 50 \\
\text { years» (FU7) }\end{array}$ & $\begin{array}{l}\text { Quantities of material and } \\
\text { energy required to meet the } \\
\text { amount of concrete needed in } \\
\text { a } 1 \mathrm{~m}^{3} \text { structure with a service } \\
\text { life of } 50 \text { years }\end{array}$ \\
\hline
\end{tabular}

The objectives of the studies: an objective consists of one or more actions which are generally allocated resources and a duration of execution. The objectives of the seven studies fell into two categories: the objectives were made up of a single main action, that of identifying hot spots (studies 1, 6 and 7); and the objectives were made up of two actions: the identification of hot spots and the comparison of alternative options (studies 2 to 5). For identical applications, the objectives to achieve the goal of the study may be different: a heterogeneity which depends on the delineation of the object of study or more precisely on the scope of the study.

The formulation of an FU: FUs are formulated in a very heterogeneous way, even when it comes to identical applications and objectives. For example, studies 1 to 3 correspond to the same type of application, but only FU2 and FU3 show features of similarity. Worse yet, studies 1, 6 and 7 or studies 2 to 5 each have the same objectives (in the sense of the number of actions they contain and their nature), but there are no apparent similarities between the FUs, neither in their formulation nor in their dimension. The only common features that can be seen visibly, such as the quantity of the service function, are insufficient to conclude on the similarity of the FUs. The lack of guidance on certain difficulties mentioned in Table 2, and the plethora of guidance on other methodological points, leads to variability in the formulation of an FU, for which we do not know the level of reliability. More sophisticated tools are needed to accurately assess their degree of similarity and quality. It is necessary to check the requirements of the definition of the FU (Table 4) then the dimensions taken into account in their definition (Table 5) and build the similarity matrices. 


\subsection{Requirements of the Definition of the Functional Unit}

The definition of the FU must include, for each object of study, the functional metric performance specific to its use and the expected exposure conditions [29]. However, the uncertainty about the end use of the object of study makes it difficult to take these performances into account, introducing a source of significant variability in the formulation of the FU. To reduce arbitrariness, the procedure provides the execution of successive steps in a hierarchical order $[4,19]$. In general, it is essential that the relevant market segment and the mandatory properties of the object of study have been determined before the expression of the functional unit. For a multifunctional object of study, it is important to start with system expansion. If the conditions for expansion are not met, resort to system disaggregation. If the object of study has many interconnected sub-processes, then allocation techniques should be used $[3,4]$. If this is not satisfactory, consider hybrid LCA with multi-objective optimization (LCA-MO) [30,31]. This procedure should be applied to all studies, but testing of the seven studies did not fully support this view (Table 4). The least fulfilled requirements concerned the identification of market segments and the use of hybrid LCA.

Identification of the market segment: Five (5) out of seven studies failed to identify the market segment of the study object. This result suggests that even if the physical quantities such as the quantity of annual production, the geographical distribution of production, the temporality of user demand or even the category of end users, would have revealed properties that are obligatory to the LCA study, they could not be taken into account in the formulation of the FU.

Identification of alternative products and processes: Only one of the seven studies did not describe alternatives of the study object. On the other hand, four out of seven studies showed alternative products and processes without first identifying the market segment concerned by the object of the study. However, alternative products and processes must be determined in this market segment.

LCA hybrid assessment: In LCA, allocation techniques should be avoided whenever possible [3,4], as the resulting study outcomes are controversial [32]. If, despite everything, allocation techniques are used, the results should be reinforced by a hybrid evaluation freed from allocation techniques [30,31]. Two out of three studies do not compare their results with those of an LCA-MO, thus making the choices made when treating multi-functionality difficult to assess.

\subsection{The Main FU Parameters}

According to the work of Cluzel [6] and those of the European Commission [17], an FU should include four dimensions structured around the functions of the object of study and introduced by a verb in the infinitive. The four dimensions are the responses to "What?", "How much?", "How well?" and "For how long?" of the object of study. Seven (7) FUs were analyzed on the presence or absence of the dimensions mentioned above (Table 5). No FU contained both the four dimensions and the introductory verb. While the "what" and "how much" dimensions are generally present in the formulation of an FU, the introductory verb and the "How well?" for "how long?" dimensions are rarely taken into account. Indeed, the guidance concerning the introduction of the FU by a verb in the infinitive is relatively recent. The first article suggesting its use dates from 2013 [6]. In addition, this suggestion of harmonization does not have the weight of a standard, hence it receives less consideration than the dimensions "how well?" for "how long?". These last two dimensions refer to a quality indicator and the lifespan of a product (or a process), respectively. While it is preferable to quantify a quality indicator, the exercise remains difficult, especially because there is no dedicated method to date. The same observation can be made on the estimation of the lifespan of products and processes. Guidance is limited to advising duration that have meaning, for example that of the actual lifespan of the product or process, or to consider the year to refer, for example, to annual production. 
Table 4. The requirements of the definition of the functional unit.

\begin{tabular}{|c|c|c|c|c|c|c|c|c|c|}
\hline & \multirow[b]{2}{*}{$\begin{array}{l}\text { Properties of the } \\
\text { Product or Process }\end{array}$} & \multirow[b]{2}{*}{ Market Segments } & \multirow[b]{2}{*}{$\begin{array}{l}\text { Product or Process } \\
\text { Alternatives }\end{array}$} & \multicolumn{6}{|c|}{ Functional Unit } \\
\hline & & & & Normal & System Expansion & $\begin{array}{c}\text { System } \\
\text { Disaggregation }\end{array}$ & $\begin{array}{l}\text { Allocation Using } \\
\text { Physical Causation }\end{array}$ & $\begin{array}{l}\text { Allocation Using } \\
\text { Other Relationships }\end{array}$ & $\begin{array}{c}\text { LCA Multi-objective } \\
\text { Optimization } \\
\text { Hybrid Assessment }\end{array}$ \\
\hline $\begin{array}{l}\text { Study 1: Boron mining and } \\
\text { processing }[11,25]\end{array}$ & $\square$ & $\square$ & $\square$ & $\square$ & $凶$ & $\square$ & $\square$ & $\square$ & $\square$ \\
\hline Study 2: Copper mining [26] & $\square$ & $\square$ & $\square$ & $\otimes$ & $\otimes$ & $凶$ & $凶$ & $\square$ & $\square$ \\
\hline $\begin{array}{l}\text { Study 3: Cobalt extraction } \\
\text { process }[27]\end{array}$ & $\square$ & $\square$ & $\square$ & $凶$ & $\square$ & $凶$ & $凶$ & $凶$ & $\square$ \\
\hline $\begin{array}{l}\text { Studies } 4 \text { and 5: Designing } \\
\text { grinding wheel, Grinding } \\
\text { process [12] }\end{array}$ & $\square$ & $\square$ & $\square$ & $\square$ & $凶$ & $凶$ & $凶$ & $凶$ & $\otimes$ \\
\hline Study 6: $\mathrm{SO}_{2}$ abatement [25] & $\square$ & $\square$ & $\square$ & $\square$ & $凶$ & $凶$ & $凶$ & $凶$ & $凶$ \\
\hline Study 7: HVFA concrete [28] & $\square$ & $\square$ & $\square$ & $\nabla$ & $凶$ & $凶$ & $凶$ & $凶$ & $凶$ \\
\hline
\end{tabular}


Table 5. Presence or absence of the main FU parameters for the six functional units of these studies.

\begin{tabular}{|c|c|c|c|c|c|}
\hline & Verb & What? & How Many? & How Well? & For How Long? \\
\hline $\begin{array}{l}\text { FU1: «Operation of the } \\
\text { system for one year» }\end{array}$ & No & Yes & No & No & Yes \\
\hline $\begin{array}{l}\text { FU2: «The production of } 1 \\
\text { kg of copper cathode» }\end{array}$ & No & Yes & Yes & No & No \\
\hline $\begin{aligned} \text { FU3: } & \text { «The production of } 1 \\
& \text { kg of cobalt» }\end{aligned}$ & No & Yes & Yes & No & No \\
\hline $\begin{array}{l}\text { FU4: «The material } \\
\text { extraction and production } \\
\text { phase of a vitrified bonded } \\
\text { grinding wheel with a } \\
\text { straight profile, an external } \\
\text { diameter of } 400 \mathrm{~mm} \text {, width } \\
\text { of } 15 \mathrm{~mm} \text { and an abrasive } \\
\text { layer thickness of } 5 \mathrm{~mm} \text { " }\end{array}$ & No & Yes & Yes & Yes & No \\
\hline $\begin{array}{c}\text { FU 5: «To produce 12,000 } \\
\text { workpieces with an } \\
\text { external cylindrical } \\
\text { grinding process» }\end{array}$ & Yes & Yes & Yes & No & No \\
\hline $\begin{array}{l}\text { FU 6: «Treatment of one } \\
\text { ton of } \mathrm{SO}_{2} \text { in the flue gas» }\end{array}$ & No & Yes & Yes & No & No \\
\hline $\begin{array}{c}\text { FU 7: «The amount of } \\
\text { concrete needed in a } 1 \mathrm{~m}^{3} \\
\text { structure with a service life } \\
\text { of } 50 \text { years» }\end{array}$ & No & Yes & Yes & No & Yes \\
\hline
\end{tabular}

\section{Discussion}

This work is entirely dedicated to the arbitrariness in the formulation of an FU and suggests an exhaustive diagnosis of the blockages encountered. The main results revealed:

1. The lack of guidance on the uncertainty about the end use of the product or process, the inclusion of stakeholder interests in the formulation of the FU, and the prioritization of functions when dealing with multifunctional systems.

2. Failure to comply with certain requirements of the definition of the FU, in particular those relating to the identification of the market segments of the subject of study, the determination of alternative products and processes, and in the case of a multi-functional objects of study with strong interconnections with co-products or sub-processes, the avoidance of allocation techniques through the use of hybrid LCA-MO evaluations.

3. The incompleteness of the configuration of the FUs was characterized by the absence of the introductory verb, indicators of quality, and durations of performance.

In this article devoted to the first part of this work, the focus is placed on the importance of the end use of the product as well as the interests of stakeholders in the formulation of the FU. Work on the prioritization of functions, requirements and functional unit settings are the subject of subsequent publications.

Studies dealing with the definition of the FU conclude that there is no regulatory framework specific to each sector of activity. They also conclude that the configuration of the FU is incomplete $[6,22]$. These conclusions corroborate the results of this study. As pointed out by several authors $[5,13,14]$, the difficulties in the selection of the functional unit mainly lie with multifunctional systems and systems that are difficult to scale. The mining sector is indeed full of this type of system. The case studies considered in this work are concrete proof of this (Table 3). In addition to revealing the 
shortcomings and the limits of the selection of the FUs, the results highlight the key points missing from the FU in the mining sector: the final utility of the product and stakeholder interests. To grasp these key points, one can indeed ask whether the cost of the life cycle of products compared to their final utility constitutes a viable or sustainable economic model. Care must be taken to approach this crucial question through the prism of the FU, in order to shed the light necessary for its adequate and complete definition. ISO 14044 states that the FU should "specify the functions (performance characteristics) of the system being studied", "be consistent with the goal and scope of the study", and be "clearly defined and measurable" [4]. The function identified should reflect the goals of the study and be based on end-use [20]. Specific components of FUs should include quantity ("how much"), quality ("how well") and duration ("how long") indicators $[6,17,33]$. This definition could be enough for most sectors except mining sectors. The mining sectors has its own characteristics in terms of its contribution to society. The existence of mining sectors for sustainable development is a necessity. Minerals are basic and essential materials for many things; therefore, the mining sector contributes to economic and social development in a variety of ways. These are:

1. Construction: To develop, maintain and enhance transport infrastructure and built environments. Without minerals, it is impossible to construct buildings, houses, roads, bridges, dams, etc.

2. Manufacturing: All of the industrial products and consumer goods are made of minerals.

3. Energy: Fossil minerals are used as energy for transportation and to generate electricity for use in houses, industry, and commerce.

4. Fertilizer: Minerals are also used as fertilizer to improve the productivity of soil.

Abundance of natural resources, especially minerals, has adverse consequences for economic development [34]. Metals are used in most modern technologies either as necessary constituents or to enhance technological efficiencies. Rare metals and rare earth metals are critical elements in high-tech industries. Analysis of industrial linkages demonstrates that mining industries are basic for national economies. The history of civilization and industrial advancement has been linked with man's ability to harness and use the materials available. Mineral resources are valuable assets. Unlike human resources, capital, knowledge, and manufacturing facilities, they are non-transferable and can only be mined where they occur. This distinguishes mining from the other industrial sectors of the economy [35]. Therefore, FUs should consider the economic and social benefits of mining sectors. Benefits from income and employment are the main positive impacts. Land use-related impacts and environmental impacts affecting human health and human rights appear to be the most concerning social aspects in the mining sector. It should be noted, however, that working conditions and human rights indicators are often considered in studies as well as methodological frameworks from the SDGs in Global Reporting Initiative (GRI) and European Union (EU), policy, and the databases used in Social Life Cycle Assessments (SLCA). On the other hand, the indicators of demographic variations and migration due to the presence of mines as well as the impacts relating to land use are less so in the reference frameworks for sustainable development [36]. However, social considerations are a crucial issue in the mining sector because social risks can generate impacts across a range of institutions, boundaries and factors [37]: "The industry must respond to sustainability challenges by engaging its many different stakeholders and addressing their sustainability concerns. The industry must also be able to measure and assess its sustainability performance and to demonstrate continuous improvements over long term" [38]. Specification of the FU and the reference flows is essential to build and model the product system. Modeling the product system is essential to identifying locations and specific stakeholders involved [24]. Thus, as the system is delineated, stakeholders are identified, and their interests are considered in the specification of an FU on an iterative basis. "The FU is the quantification of function that the product system delivers and is used as a basis for calculating the potential impacts" [39]. An inappropriate choice of FU may result in less reliable LCA studies, going so far as to alter the apparent favorable option [8-12]. Comparatives LCA studies are probably the most sensitive to the choice of FU. Several authors from various fields report radically different 
conclusions that depend on the FU chosen [8-12,39,40]. Such conclusions have the effect of misleading stakeholders. Decision-makers must be able to identify and favor virtuous systems. To limit the effects of errors, Salou et al. recommend using several FUs for the same study in order to highlight all the implications [40]. At the same time, Matheys et al. indicate that when using a realistic FU, the results of LCA studies are not significantly influenced by the choice of FU [10]. There must be a way to reconcile these conflicting observations, in the way this study explores.

One of the strengths of this study concerns the research plan implemented. The complexity of the definition of the FU is considered from a reduced number of case studies. All the aspects and characteristics of mining, whether environmental, economic, social, or mixed, have been described and their effects analyzed. The comparison of the cases allowed the abstraction of common elements and the identification of particularities of the definition of the FU in the mining sector. However, certain limitations must be considered. In particular, the transferability of the results of this study to other sectors of activity cannot be envisaged without prior adaptation, given the diversity of the contexts in which the products, processes and systems operate.

\section{Conclusions}

It has been seen that the FU is not properly defined in the mining sector. It does not consider the key parameters of the final utility of the product (or process) and the interests of stakeholders. It is for this reason that it would be difficult to compare, for example, the production of copper or alumina between two regions of the earth, as this does not only require considering the production process, but the whole environment around production: environmental aspects such as pollution which affect human health; economic aspects such as employee income, number of jobs, contribution to the national economy; and social aspects such as working conditions, human rights, demographic variations and migration due to the presence of the mine as well as impacts relating to land use.

Integrating all these parameters into the FU requires both a precise and concise methodology in future research.

Author Contributions: Conceptualization, B.L. and J.B.; methodology, J.B. and B.L.; validation, B.L., B.E. and J.B.; formal analysis, J.B., B.L. and B.E.; investigation, J.B.; resources, J.B., B.L. and B.E.; data curation, J.B., B.L. and B.E.; writing —original draft preparation, J.B.; writing—-review and editing, J.B.; visualization, J.B.; supervision, B.L. All authors have read and agreed to the published version of the manuscript.

Funding: This paper has been produced benefiting from the 2232 International Fellowship for Outstanding Researchers Program of TÜBITAK (Project No: 118C219). However, the entire responsibility of the paper belongs to the owner of the paper. The financial support received from TÜBITAK does not mean that the content of the publication is approved in a scientific sense by TÜBİTAK.

Acknowledgments: Thank you to Ivan Iordanoff for allowing the collaboration, the first fruits of which are reaching maturity. "If you sow good seeds in good soil, the fruits will be very abundant." Manchurian proverb; Chrestomathie Manchou (1828). Let us never hesitate to sow ours in return.

Conflicts of Interest: The authors declare no conflict of interest.

\section{References}

1. History of LCA. Available online: https://www.eco-conception.fr/static/histoire-acv.html (accessed on 15 July 2020).

2. Guinée, J.B.; Heijungs, R.; Huppes, G.; Zamagni, A.; Masoni, P.; Buonamici, R.; Ekvall, T.; Rydberg, T. Life Cycle Assessment: Past, Present, and Future. Environ. Sci. Technol. 2011, 45, 90-96. [CrossRef]

3. International Organisation for Standardization (ISO). Environmental Management-Life Cycle Assessment-Principles and Framework. 2006. Available online: http:/www.cscses.com/uploads/2016328/ 20160328110518251825.pdf (accessed on 10 October 2020).

4. International Organisation for Standardization (ISO). Environmental Management-Life Cycle Assessment-Requirements and Guidelines. 2006. Available online: https://www.iso.org/standard/38498. html (accessed on 10 October 2020). 
5. Reap, J.; Roman, F.; Duncan, S.; Bras, B. A survey of unresolved problems in life cycle assessment. Part 1: Goal and scope and inventory analysis. Int. J. Life Cycle Assess 2008, 13, 290. [CrossRef]

6. Cluzel, F.; Leroy, Y.; Yannou, B. Toward a Structured Functional Unit Definition Framework to Limit LCA Results Variability. In Proceedings of the 6th International Conference on Life Cycle Management in Gothenburg, Gothenburg, Sweden, 25-28 August 2013; p. 484.

7. Collado-Ruiz, D.; Ostad-Ahmad-Ghorabi, H. Fuon theory: Standardizing functional units for product design. Resour. Conserv. Recycl. 2010, 54, 683-691. [CrossRef]

8. Choudhary, S.; Liang, S.; Cai, H.; Keoleian, G.A.; Miller, S.A.; Kelly, J.; Xu, M. Reference and functional unit can change bioenergy pathway choices. Int. J. Life Cycle Assess 2014, 19, 796-805. [CrossRef]

9. Kim, S.; Dale, B. Ethanol fuels: E10 or E85-life cycle perspectives (5 pp). Int. J. Life Cycle Assess 2006, 11, 117-121. [CrossRef]

10. Matheys, J.; Van Autenboer, W.; Timmermans, J.-M.; Van Mierlo, J.; Van Den Bossche, P.; Maggetto, G. Influence of functional unit on the life cycle assessment of traction batteries. Int. J. Life Cycle Assess 2007, 12, 191. [CrossRef]

11. Azapagic, A.; Clift, R. Life cycle assessment as a tool for improving process performance: A case study on boron products. Int. J. LCA 1999, 4, 133. [CrossRef]

12. Winter, M.; Ibbotson, S.; Kara, S.; Herrmann, C. Life cycle assessment of cubic boron nitride grinding wheels. J. Clean. Prod. 2015, 107, 707-721. [CrossRef]

13. Cooper, J.S. Specifying functional units and reference flows for comparable alternatives. Int. J. LCA 2003, 8, 337. [CrossRef]

14. Finkbeiner, M.; Ackermann, R.; Bach, V.; Berger, M.; Brankatschk, G.; Chang, Y.-J.; Grinberg, M.; Lehmann, A.; Martínez-Blanco, J.; Minkov, N.; et al. Challenges in Life Cycle Assessment: An Overview of Current Gaps and Research Needs. In Background and Future Prospects in Life Cycle Assessment; Klöpffer, W., Ed.; Springer: Dordrecht, The Netherlands, 2014; pp. 207-258. ISBN 978-94-017-8697-3.

15. Reap, J.; Roman, F.; Duncan, S.; Bras, B. A survey of unresolved problems in life cycle assessment. Part 2: Impact assessment and interpretation. Int. J. Life Cycle Assess 2008, 13, 374. [CrossRef]

16. Langfitt, Q.M. Analyses of Functional Unit and Normalization Options for Presentation of Transportation Life Cycle Assessment Results; Washington State University: Pullman, WA, USA, 2017.

17. European Commission-Joint Research Centre-Institute for Environment and Sustainability. General Guide for Life Cycle Assessment—Detailed Guidance. 2010. Available online: https:/eplca.jrc.ec.europa.eu/uploads/ ILCD-Handbook-General-guide-for-LCA-DETAILED-GUIDANCE-12March2010-ISBN-fin-v1.0-EN.pdf (accessed on 10 October 2020).

18. Günther, A.; Langowski, H.-C. Life cycle assessment study on resilient floor coverings. Int. J. LCA 1997, 2, 73-80. [CrossRef]

19. Weidema, B.; Wenzel, H.; Petersen, C.; Hansen, K. The Product, Funcional Unit and Reference Flow in LCA. Environ. News 2004, 70, 1-46.

20. Guinée, J.B.; Lindeijer, E. Handbook on Life Cycle Assessment: Operational Guide to the ISO Standards; Springer Science \& Business Media: Berlin/Heidelberg, Germany, 2002; ISBN 978-1-4020-0228-1.

21. Klöpffer, W.; Grahl, B. Life Cycle Assessment (LCA): A Guide to Best Practice; John Wiley \& Sons: Hoboken, NJ, USA, 2014; ISBN 978-3-527-65564-9.

22. Collado-Ruiz, D.; Ostad-Ahmad-Ghorabi, H. Comparing LCA results out of competing products: Developing reference ranges from a product family approach. J. Clean. Prod. 2010, 18, 355-364. [CrossRef]

23. Esterman, M., Jr.; Fumagalli, M.E.; Thorn, B.; Babbitt, C. A framework for the integration of system engineering and functional analysis techniques to the goal and scope of life cycle assessment. In Proceedings of the International Design Engineering Technical Conferences and Computers and Information in Engineering Conference, Chicago, IL, USA, 12-15 August 2012; American Society of Mechanical Engineers: New York, NY, USA, 2012; Volume 45042, pp. 777-787.

24. Crotty, B. UNEP: Guidelines for Social Life Cycle Assessment of Products 2009. Available online: https: //wedocs.unep.org/handle/20.500.11822/7912 (accessed on 10 October 2020).

25. Azapagic, A. Life cycle assessment and its application to process selection, design and optimisation. Chem. Eng. J. 1999, 73, 1-21. [CrossRef] 
26. Kampmann, T.C.; Alvarenga, R.A.F.; Sanjuan-Delmás, D.; Lindblom, M. Life cycle assessment of European copper mining: A case study from Sweden. In Proceedings of the 15th SGA Biennial Meeting, Glasgow, UK, 27-30 August 2019; Society for Geology Applied to Mineral Deposits: Glasgow, Scotland, 2019; Volume 4, pp. 1577-1580.

27. Farjana, S.H.; Huda, N.; Mahmud, M.A.P. Life cycle assessment of cobalt extraction process. J. Sustain. Min. 2019, 18, 150-161. [CrossRef]

28. Van den Heede, P.; De Belie, N. Durability Related Functional Unit for Life Cycle Assessment of High-Volume Fly Ash Concrete; UWM Center for By-Products Utilization: Milwaukee, WI, USA, 2010; pp. 583-594.

29. Panesar, D.K.; Seto, K.E.; Churchill, C.J. Impact of the selection of functional unit on the life cycle assessment of green concrete. Int. J. Life Cycle Assess 2017, 22, 1969-1986. [CrossRef]

30. Azapagic, A.; Clift, R. Allocation of environmental burdens in co-product systems: Product-related burdens (Part 1). Int. J. LCA 1999, 4, 357. [CrossRef]

31. Azapagic, A.; Clift, R. Life cycle assessment and multiobjective optimisation. J. Clean. Prod. 1999, 7, 135-143. [CrossRef]

32. Schrijvers, D.L.; Loubet, P.; Sonnemann, G. Developing a systematic framework for consistent allocation in LCA. Int. J. Life Cycle Assess 2016, 21, 976-993. [CrossRef]

33. Simonen, K. Life Cycle Assessment; Routledge: Abingdon-on-Thames, UK, 2014; ISBN 978-1-317-69736-7.

34. Wright, G.; Czelusta, J. Why Economies Slow: The Myth of the Resource Curse. Challenge 2004, 47, 6-38. [CrossRef]

35. Highley, D.E.; Chapman, G.R.; Bonel, K.A. The Economic Importance of Minerals to the UK. Available online: http://nora.nerc.ac.uk/id/eprint/509640/ (accessed on 1 October 2020).

36. Mancini, L.; Sala, S. Social impact assessment in the mining sector: Review and comparison of indicators frameworks. Resour. Policy 2018, 57, 98-111. [CrossRef]

37. Kemp, D.; Worden, S.; Owen, J.R. Differentiated social risk: Rebound dynamics and sustainability performance in mining. Resour. Policy 2016, 50, 19-26. [CrossRef]

38. Azapagic, A. Developing a framework for sustainable development indicators for the mining and minerals industry. J. Clean. Prod. 2004, 12, 639-662. [CrossRef]

39. Mungkung, R.; Gheewala, S.H. Use of life cycle assessment (LCA) to compare the environmental impacts of aquaculture and agri-food products. FAO Fish Process. 2007, 10, 87-96.

40. Salou, T.; Le Mouël, C.; van der Werf, H.M.G. Environmental impacts of dairy system intensification: The functional unit matters! J. Clean. Prod. 2017, 140, 445-454. [CrossRef]

Publisher's Note: MDPI stays neutral with regard to jurisdictional claims in published maps and institutional affiliations.

(C) 2020 by the authors. Licensee MDPI, Basel, Switzerland. This article is an open access article distributed under the terms and conditions of the Creative Commons Attribution (CC BY) license (http://creativecommons.org/licenses/by/4.0/). 